\title{
Process Of Egg Salt Smoke In Htm Jaya Brebes
}

\author{
Hanna Rizqi Nurbaety ${ }^{1}$, Nurwati ${ }^{2}$ \\ 1,2Program Studi Ilmu dan Teknologi Pangan, Fakultas Sains dan Teknologi Pangan, Universitas Muhadi \\ Setiabudi Brebes \\ e-mail: hana1riski@gmail.com,nurwanti@umus.ac.id
}

\begin{abstract}
Local ducks in Indonesia are generally kept as one of the egg producers. This study aims to determine the processing of salted smoked eggs in HTM Jaya. This research was conducted in HTM Jaya which is engaged in processing salted eggs for 30 days. The approach used is a qualitative approach, so that the researcher can describe all events during the research process. The data sources used are primary data and secondary data. Raw materials for duck eggs are obtained from two places, namely the pesantunan village and the jatibarang village. the incubation time is 12 days. The smoking is carried out for 4-6 hours with hot coals (coconut shell charcoal) which must always burn stably. Packaging is done after the eggs are smoked and aerated until warm. Packaging is done using a box, the reason for using a box is because it is more practical and affordable. In each box package there are 10 eggs.
\end{abstract}

Keywords: egg ; salt ; smoke, HTM, Brebes

\section{INTRODUCTION}

Local ducks in Indonesia are generally kept as one of the egg producers. Eggs are one of the food ingredients from livestock which have high nutritional value because they contain food substances that are needed by the human body such as vitamins, complete and balanced amino acids and have high digestibility. Salted eggs are one of the processed egg products that have been widely accepted by the community. Salted egg is a term for food made from eggs that are preserved by salting. The eggs that are usually made salted eggs are duck eggs. These salted eggs are practical and can be combined with various dishes.

This is inseparable from the advantages of the salted egg itself, such as its distinctive flavor, longer shelf life and attractive appearance. Duck eggs have a slightly fishy taste, an attractive egg yolk color (dark yellow), a larger size and a more attractive color (bluish green), this is the reason why people prefer and accept duck eggs as raw material for salted eggs. .

Salted eggs are fresh eggs that are processed intact and preserved, as well as salted using the main ingredient of salt. In principle, the process of making salted eggs is salting. The salty taste of the eggs is due to the osmosis process in the eggs, namely the $\mathrm{NaCl}$ salt will initially be converted into sodium ions $(\mathrm{Na}+)$ and chlorine ions $(\mathrm{Cl}-)$. The solution of salt $(\mathrm{NaCl})$ will enter the eggs through the skin pores, leading to the white part, and finally to the yolk [1].

Basically, the process of making salted eggs has several ways. However, most people prefer to be soaked or wrapped in salt dough mixed with red brick powder, clay, or rubbing ash. Each method of salting has its own privileges. The traditional salting method using mixed media in the form of salt, brick powder and rubbing ash will produce eggs that have a distinctive taste and are preferred [2]. However, there is a relatively large reduction in weight due to diffusion of water and evaporation of water and gas out of the egg coupled with the fumigation treatment at the end of the process. At this time the innovation of salted smoked eggs has begun to be recognized.

Brebes Regency is one of the areas famous for its salted egg products. To increase the added value of the salted eggs, some salted egg craftsmen process salted eggs into smoked salted eggs. The smoking process will produce salted eggs that have a different appearance and taste from regular salted eggs. The process of ripening smoked salted eggs can be done by various 
methods, including boiling and smoking. Fumigation is one of the processing techniques for smoking eggs that have been done from a long time ago, smoking is also a smoke method by preserving salted eggs so that many smoked eggs have begun to be made by salted egg producers besides smoking also increases the economic value of these eggs. After smoked salted egg, it has its own distinctive taste and the taste is suitable for the community. This study aims to determine the processing of salted smoked eggs in HTM Jaya

\section{RESEARCH METHODS}

This research was conducted in HTM Jaya which is engaged in processing salted eggs for 30 days. The approach used is a qualitative approach, so that the researcher can describe all events during the research process.

The data sources used are primary data and secondary data. Primary data obtained by interview and observation [3]. Interviews were conducted with owners and employees of HTM Jaya. Secondary data were obtained from the document records of activities that occurred at HTM Jaya.

\section{DISCUSSION}

\section{Receiving Raw Materials}

The raw material used in the process of making smoked salted eggs is the original Brebes duck egg, which is widely available in Indonesia, and its cultivation has also been widely practiced among Indonesians.

Raw materials are obtained from breeders directly from Pesantunan and Jatibarang villages. The travel time from livestock to HTM Jaya is \pm 2 days, by using motorbike transportation to the processing plant and washing it immediately to remove duck dung that is still attached to the egg body. For one time the production of smoked salted eggs requires 500 duck eggs for smoked eggs and for original salted eggs up to 1000 more duck eggs, but if the price of duck eggs decreases from the usual price, the business owner can buy more duck eggs. much to reduce outlay against raw material prices. The table for the price of duck eggs from breeders can be seen in table 1 .

Table 1. Price of Duck Egg Raw Material from Two Collecting Villages

\begin{tabular}{cc}
\hline Acquisition of Raw Materials & Egg Prices \\
\hline Pesantunan & Rp. 1.900 \\
Jatibarang & Rp. 2.500 \\
\hline
\end{tabular}

The selling price of smoked salted eggs at HTM Jaya is Rp. 4,000, so that the profit margin you get is also quite large if HTM is victorious every day can sell 500 items.

\section{Washing}

Washing is done after the raw materials are received directly from the farmer. The washing uses rice husks so that the egg pores open properly without injuring the egg shells. This activity functions to remove dirt from the eggshell, open the shell pores, and reduce the thickness of the eggshell so that salt can penetrate more quickly. The process of washing eggs can be seen in Figure 1. 


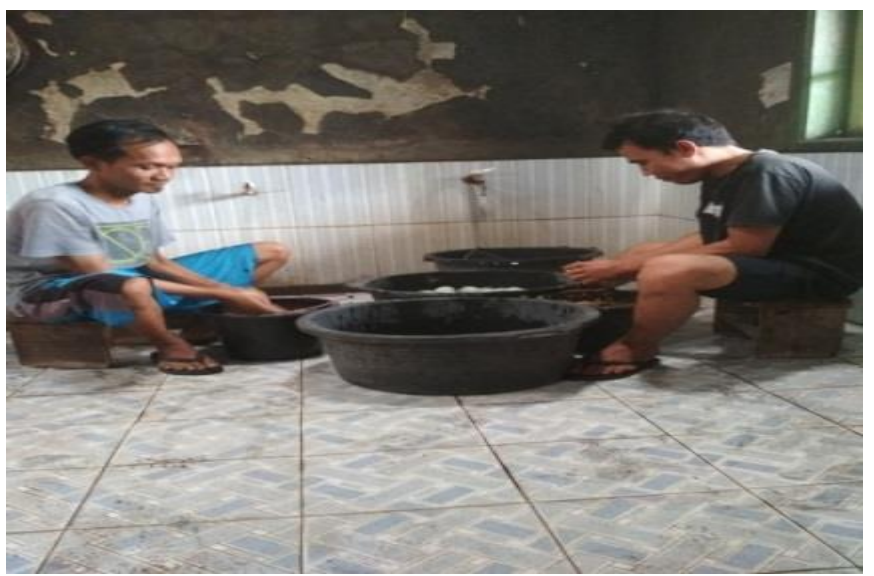

Picture 1 . Egg Washing Process at HTM Jaya

\section{Egg dressing}

The kneading process is carried out after going through the washing process using a mixture of dough in a ratio of 1: 2: 3, 1 for brick powder, 2 for salt, 3 for rubbing ash. The function of laying is so that the salt liquid enters the egg through the pores of the eggshell. The laying process can be seen in Figure 2.

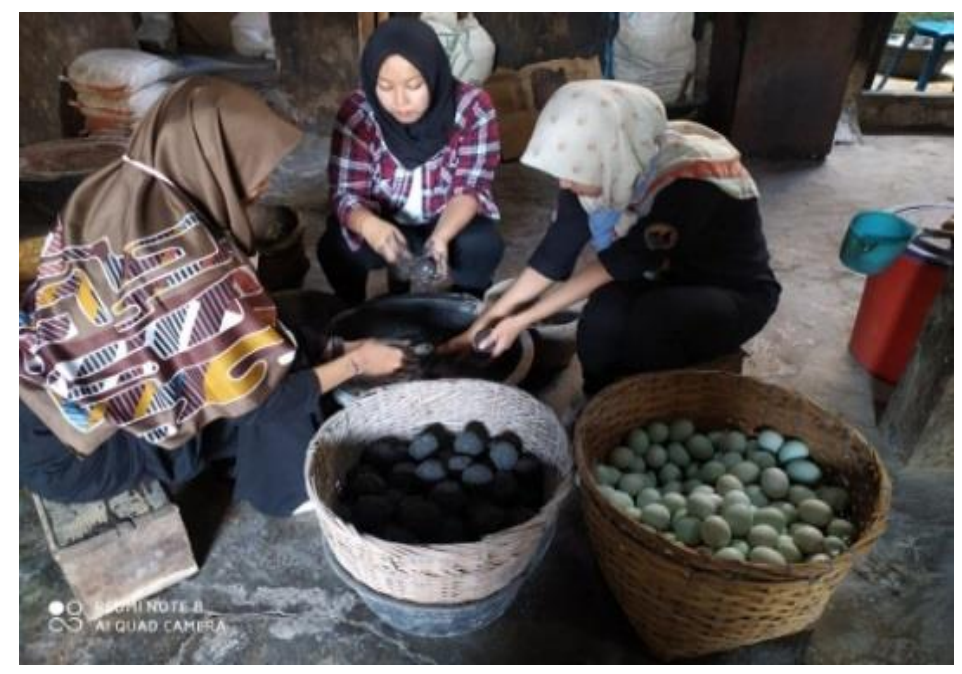

Figure 2. Distribution of Duck Eggs at UKM Jaya

\section{Incubation}

The incubation process is carried out after going through the laying process, in this process it is generally carried out for 12 days, but in the production process of HTM Jaya smoked salted eggs, the incubation process is carried out for 2 weeks in order to get good results on the egg yolk. This activity serves to wait for the results of the salting process [4].

\section{Boiling eggs}

Boiling is done after going through the incubation process for 2 weeks. Boiling aims to make the eggs fully cooked besides that it also helps improve the texture of the eggs to become 
chewy. Boiling is done using a pot on the stove for 4 hours, but in order to get good results, it would be better if it was done for 6 hours.

The boiling process functions so that the eggs are cooked, increase the tenderness of the egg meat, increase the coagulation of the meat structure due to partial coagulation of protein to provide a certain taste and aroma, provide a more attractive color due to denaturation of myoglobin, the formation of nitrosohemochromes, pasteurization and therefore prolong the shelf life of egg products 5]. Cooking can be done by boiling, steaming, smoking, or a combination of the three. The boiling process can be seen in Figure 3 .
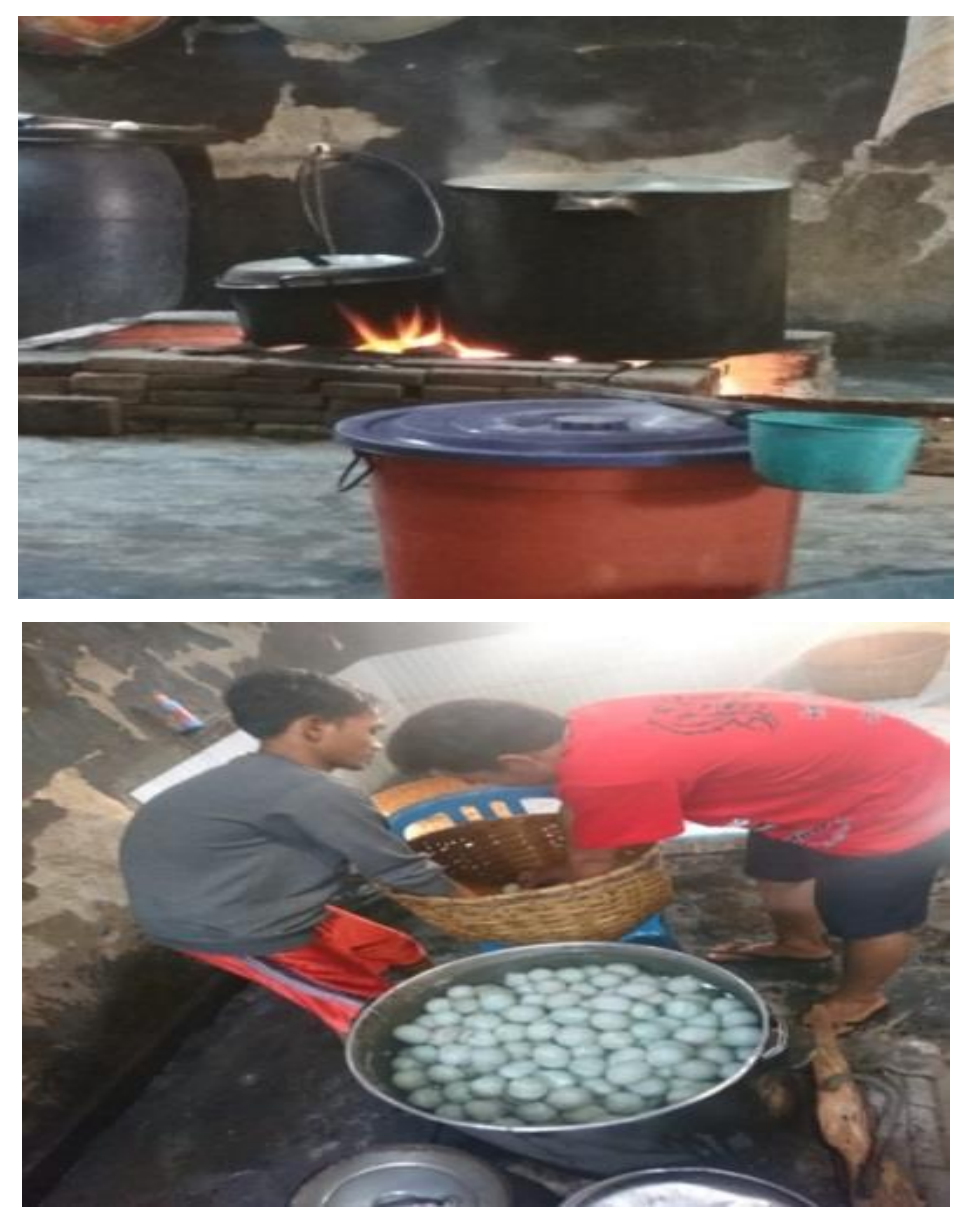

Picture 3. Egg Boiling Process at HTM Jaya

\section{Fumigation}

Fumigation is carried out after going through the boiling and sorting process, the eggs that block the damage to the skin (spots) will be used for smoked salted eggs. The smoking is carried out for 4-6 hours with hot coals (coconut shell charcoal) which must always burn stably. This smoking function is to produce salted eggs which taste smoky and drier than boiled eggs [2]. The smoking process can be seen in Figure 4. 


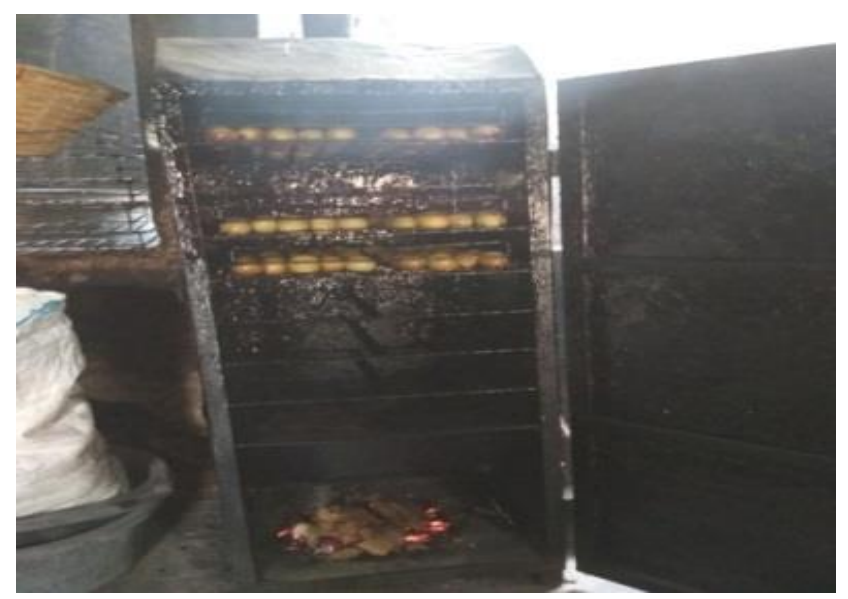

Figure 4. Fumigation Process at HTM Jaya

\section{Packaging}

Packaging is done after the eggs are smoked and aerated until warm. Packaging is done using a box, the reason for using a box is because it is more practical and affordable. In each box package there are 10 eggs. Packaging is a way of providing the right surrounding conditions for foodstuffs. Good packaging is a package that can prevent or reduce damage to foodstuffs, as well as protect the food contained therein and physical disturbances (friction, collision, vibration) [6]. The packaging process can be seen in figure 5 .
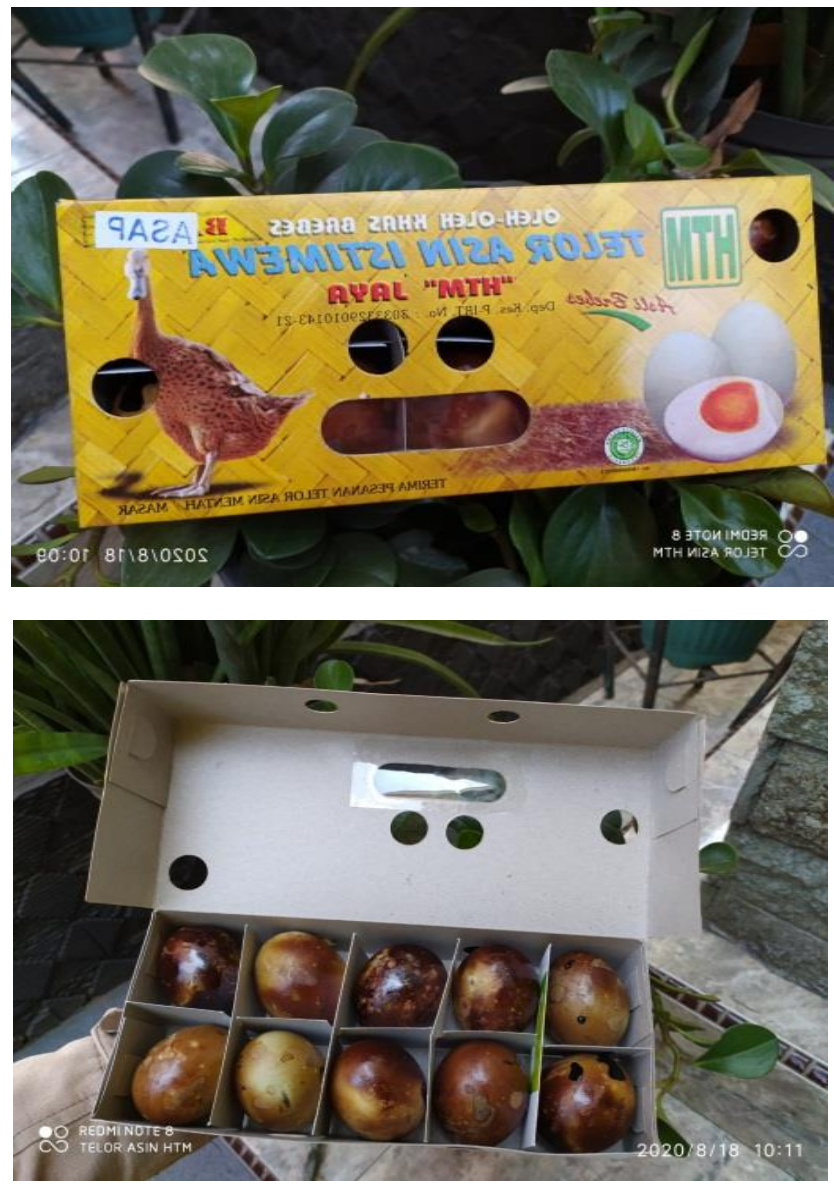

Figure 5. Egg Packaging at HTM Jaya 


\section{CONCLUSION}

Salted eggs that have been boiled can still be made into smoked salted eggs by smoking them for 4-6 hours using acid from hot coals (coconut shell charcoal) which must always be burning stably.

\section{Acknowledgement}

Thank you to Mr. Muhamad Hasdar who has guided and helped finalize this article for publication and HTM Jaya Brebes place this research.

\section{References}

[1] L. Xu et al., 'Effects of salting treatment on the physicochemical properties, textural properties, and microstructures of duck eggs', PLoS One, vol. 12, no. 8, pp. 1-17, 2017.

[2] J. M. . Wibawanti, M. Meihu, A. Hintono, and Y. B. Pramono, 'The Characteristes Of Salted Egg In The Presence Of Liquid Smoke', J. Appl. Food Technol., vol. 3, no. 2, pp. 193-198, 2015.

[3] M. Ciesielska and D. Jemielniak, 'Qualitative methodologies in organization studies', Qual. Methodol. Organ. Stud., vol. 2, no. December, pp. 1-264, 2017.

[4] T. H. Wang, 'Salting yolks directly using fresh duck egg yolks with salt and maltodextrin', J. Poult. Sci., vol. 54, no. 1, pp. 97-102, 2017.

[5] T. Kaewmanee, S. Benjakul, and W. Visessanguan, 'Effect of salting processes on chemical composition, textural properties and microstructure of duck egg', J. Sci. Food Agric., vol. 89, no. 4, pp. 625-633, 2009.

[6] Rukmiasih, N. Ulupi, and W. Indriani, 'Sifat Fisik, Kimia Dan Organoleptik Telur Asin Melalui Penggaraman Dengan Tekanan Dan Konsentrasi Garam Yang Berbeda', J. Ilmu Produksi dan Teknol. Has. Peternak., vol. 3, no. 3, pp. 142-145, 2015. 